\title{
CO-COMBUSTION OF PULP- AND PAPER SLUDGE WITH WOOD - EMISSIONS OF NITROGEN, SULPHUR AND CHLORINE COMPOUNDS
}

\author{
Lars-Erik Åmand*
}

Solvie Herstad Svärd**

David Eskilsson ${ }^{\star * *}$
Bo Leckner*

\author{
Marianne Gyllenhammar**
}

Claes Tullin***

\author{
*Department of Energy Conversion, Chalmers University of Technology, \\ SE-412 96 Göteborg, Sweden \\ ${ }^{* *}$ Scandinavian Energy Project AB, \\ Bror Nilssons Gata 16, SE-417 55 Göteborg, Sweden \\ ${ }^{* * *}$ SP, Swedish National Testing and Research Institute \\ P.O Box 857, SE-501 15 Borås
}

\begin{abstract}
Sludge from wastewater treatment plants in five Swedish pulp and paper mills has been burned together with wood in a circulating fluidised bed (CFB) boiler. The sludge was either mechanically dewatered or pre-dried. The mechanically dewatered sludge had to be fed with a pump, but the pre-dried sludge could be fed by the fuel feed system normally used for coal, wood chips or wood pellets. In parallel to the combustion tests in the CFB boiler the sludges were also investigated as single fuels in a small laboratory FB.

The Swedish pulp and paper industry produces three major fractions of sludge: pure fibre sludge, sludge produced by employing a precipitation species like ironaluminiumsulphate, and finally, sludge subjected to biological cleaning. The way of production of the sludge influences its content of, for example, nitrogen, sulphur and chlorine, but the composition of the sludge is also influenced by the pulp and paper process. The present measurements show that the concentrations of nitrogen, sulphur and chlorine in the sludge have a great impact on the corresponding gaseous emissions from combustion. Actions to prevent these emissions could be necessary, depending on the origin of the sludge and treatment process used. In the present project all sludges were burned with wood-pellets as the main fuel under identical operating conditions, typical for a CFB boiler. Wood pellets were chosen as a well defined, lowpolluting fuel that makes comparison of emissions from the sludges clear. Co-combustion with wood-pellets has the advantage of enabling operation also with wet sludges that cannot be used as single fuels without pre-drying. No actions
\end{abstract}

were taken to improve sulphur and chlorine retention, by for example adding limestone. From a combustion point of view the co-combustion works well with low levels of carbon monoxide present in the flue gas and no light hydrocarbons.

\section{INTRODUCTION}

The use of land filling as a means of deposition of pulp\&paper mill sludge is becoming more difficult because of increasing environmental demands on disposal sites. Lack of suitable locations for disposal sites and increasing costs for preparation makes land filling an expensive alternative in the future. Thermal treatment could be a better solution to the problem. With a proper technology the energy content can be recovered, and in the case of co-combustion with coal an effective reduction of the $\mathrm{CO}_{2}$ emission is achieved. Combustion of pulp\&paper mill sludge in fluidised bed boilers has been demonstrated in a number of publications [1-7]. The sludge was either burned as a single fuel [1], together with coal [3-6], or biomass [2] or other refuse derived fuels [7]. Unlike the situation described in these papers, where only one type of sludge was studied at the time, here results are presented from different kinds of pulp\&paper mill sludges. The selection of sludges aimed at achieving a difference in, for example, the content of nitrogen, sulphur and chlorine and to study the corresponding emissions. 


\section{EXPERIMENTAL BACKGROUND}

\section{The Boiler}

The $12 \mathrm{MW}_{\text {th }}$ circulating fluidized bed (CFB) boiler, located at Chalmers University of Technology was used for the tests, Figure 1. The boiler is built for research but has all the features of a commercial unit. The combustion chamber (1) has a square cross-section of about $2.25 \mathrm{~m}^{2}$ and a height of $13.6 \mathrm{~m}$. Fuel is fed to the bottom of the combustion chamber through a fuel chute (7). The circulating solids are separated in the primary cyclone (2) and transported through the particle return leg (3), the loop seal (4), and, during combustion of pure wood pellets, also through the external heat exchanger (5), back into the combustion chamber. Primary combustion air is supplied to the wind box (6) below the gas distributor, and secondary air was supplied in (9). The other secondary air ports (10-12) were not used. After passing the exit duct of the cyclone (13), the flue gases are cooled to $150{ }^{\circ} \mathrm{C}$ in the convection path and fly ash is separated from the flue gases, first in a secondary cyclone and then in a bag filter.

\section{The Laboratory Test Unit}

The laboratory unit, Figure 2, consists of a quartz glass reactor (inner diameter $=0.07 \mathrm{~m}$, length $=1.5 \mathrm{~m}$ ), surrounded by an electrically heated oven that can be controlled up to 1100 ${ }^{\circ} \mathrm{C}$. The wet sludge was dried and briquetted into pieces of $2 \mathrm{~g}$ each. The briquettes were fed into the reactor one by one through a carousel feeder $(6 \mathrm{~g} / \mathrm{min})$. The bed temperature was measured with an unshielded thermocouple and was kept constant at $850{ }^{\circ} \mathrm{C}$. The relation between primary and secondary air was 3:1.The flue gas was sampled in the top of the reactor with a heated probe. After filtration the sample gas was distributed to the gas analysers.

\section{The Fuels}

The wood pellets were produced from saw dust (pine) by "AB Svensk Brikettenergi". The sludges originated from wastewater treatment plants of five Swedish pulp and paper mills. The sludge consists mainly of three fractions: pure fibre sludge, sludge produced by chemical precipitation or by a biological cleaning step. Depending on the arrangement in the mills, each of the six different sludges in the test program was either a mixture of fibre sludge and chemically precipitated sludge, or pure fibre sludge or pure biological sludge. From Table 1 the origin of sludges is declared together with their properties related to combustion. One of the sludges was predried, while the other five were mechanically dewatered to various moisture contents, as can be seen in Table 1. In order to feed the wet sludge cake into the boiler a sludge pump (a development of a piston pump normally used for cement) was installed in the research facility.

\section{Experimental Procedure}

The operating conditions of the tests are given in Table 2 (pre-dried sludge) and Table 3 (wet sludges). The arrangements of the research boiler allows to keep the operating conditions similar in all tests, only changing the amount of sludge added and type of sludge. It is possible to feed higher fractions of predried sludge than mechanically dewatered sludge, as reflected in the test series with Sludge 1 (Table 2) compared to the wet sludges of Table 3 . The operating conditions were chosen to represent a typical case of a CFB boiler with a bottom bed temperature of $850{ }^{\circ} \mathrm{C}$, an excess air ratio of 1.2 , splitting of air supply into primary and secondary air, inlet of secondary air at 2.2 meter and a load corresponding to a fluidising velocity of 5 $\mathrm{m} / \mathrm{s}$ at the top of the combustion chamber. No lime was added to the combustion chamber, and the emissions of sulphur dioxide $\left(\mathrm{SO}_{2}\right)$ and hydrogen chloride $(\mathrm{HCl})$ reach values that reflect the concentrations of sulphur and chlorine in the fuel.

\section{Measurements of Emissions}

Emissions were recorded in the flue gas duct ahead of the flue gas fan by three independent gas-analysing systems. The first system, A (Figure 3) consists of at set of analysers that measure the emissions of $\mathrm{SO}_{2}$, nitric oxide (NO), nitrous oxide $\left(\mathrm{N}_{2} \mathrm{O}\right)$ and carbon monoxide $(\mathrm{CO})$ on dry flue gases. The second set of analysers, B (Figure 4) is similar to the first one. These analysers are normally used for analysing gases sampled from the furnace, but they can be operated in parallel with the A-system as a backup and check. In the B system a total hydrocarbon analyser, equipped with a flame ionisation detector (FID), is included. The third system consists of an online Fourier Transform Infra-Red (FTIR) analyser, Figure 5. This instrument is developed for flue gases from a waste incinerator and hot combustion gases $\left(200^{\circ}\right)$ are withdrawn from the flue gas duct to analyse gases like ammonia, $\left(\mathrm{NH}_{3}\right)$, $\mathrm{HCl}$ and hydrogen fluoride (HF) without any condensation of moisture. Apart from these three gases $\mathrm{NO}, \mathrm{SO}_{2}, \mathrm{CO}, \mathrm{N}_{2} \mathrm{O}$ and $\mathrm{NO}_{2}$ are also measured by the FTIR and for some of the gases ( $\mathrm{NO}, \mathrm{SO}_{2}, \mathrm{~N}_{2} \mathrm{O}$ and $\mathrm{CO}$ ) a comparison of the results from the various analysis systems is possible. The gas analysis system used in the laboratory tests is similar to those at the CFB boiler. This allows a comparison between the units as well.

\section{RESULTS}

\section{Predried Pulp and Paper Sludge}

The results from burning the pre-dried sludge (Sludge 1) are given in Figures 6-8. Figure 6 focuses on the nitrogen compounds. Table 1 shows that the nitrogen content in Sludge $1(1.34 \%)$ is much higher (15 times) than that of the wood pellets $(0.09 \%)$. This increase in the amount of nitrogen when feeding sludge into the boiler is reflected in a subsequent increase of various nitrogen-containing species in the stack, as seen in Figure 6, mainly as $\mathrm{NO}$, and to some extent $\mathrm{N}_{2} \mathrm{O}$, but not as $\mathrm{NO}_{2}$ or $\mathrm{NH}_{3}$. The trends for $\mathrm{NO}$ and $\mathrm{N}_{2} \mathrm{O}$ are verified by the independent analysers. $\mathrm{NO}$ is better analysed with the chemiluminescence instrument, while $\mathrm{N}_{2} \mathrm{O}$ is better represented by FTIR. This is because the cross-sensitivities arising from $\mathrm{CO}, \mathrm{CO}_{2}, \mathrm{H}_{2} \mathrm{O}$ and $\mathrm{SO}_{2}$ are better eliminated in the FTIR than by a standard analyser. Also sulphur and chlorine are present in higher concentrations in the sludge than in the pellets. No actions, like lime supply to the furnace or hydrated lime to the bag filter, were taken to capture these species and they end up 
as emissions, Figure 7, 8. However, calcium is supplied with the ash (Table 1), corresponding to a molar ratio of $\mathrm{Ca} / \mathrm{S}$ between 0.8-1.3 in the three tests, and a mass balance shows that some sulphur is captured by this natural source of calcium. The increase of $\mathrm{SO}_{2}$ in the stack is so large that the precalibrated range of the FTIR was exceeded. Therefore, the online ultraviolet (UV) analyser follows the actual $\mathrm{SO}_{2}$ concentration better, while a deviation from this curve is seen for the FTIR at higher concentrations. There is a difference in the trends of $\mathrm{HF}$ and $\mathrm{HCl}$, Figure 8. $\mathrm{HF}$ remains almost constant at levels close to the detection limit for the FTIR analyser, whereas the $\mathrm{HCl}$ concentration rises. $\mathrm{CO}$ and total hydrocarbons (HC-tot.) both indicate a reasonable degree of burnout, but the $\mathrm{CO}$ emission increases with the ratio of sludge. The pre-dried sludge (Sludge 1) contained a high fraction of fines, causing spikes in $\mathrm{CO}$ and $\mathrm{HC}$-tot. that increased with the sludge ratio and resulted in a rise in the average $\mathrm{CO}$ emission. The $\mathrm{CO}$ and HC-tot. spikes are illustrated in Figure 9, showing a transient from the lowest feed rate of sludge to the highest.

\section{Wet Pulp and Paper Sludge}

Wet sludge was fed into the boiler by the sludge pump. The pump worked best with sludge from the biological treatment step used to produce Sludge 3.This sludge is similar to sludge produced in municipal sewage wastewater treatment plants [8] and forms a toothpaste-like medium that does not get stuck in the cylinders of the piston pump, the heart of the sludge feed arrangement. Fibre sludge, on the other hand, could not be fed through the sludge pump, and instead this material had to be introduced using a fuel hopper and a screw feeder, originally built for saw dust. The other sludges, mixtures of fibre and chemically precipitated sludges, were fed by the sludge pump. Their viscosity is higher than that of sludge from a biological treatment step, but not as high as that of pure fibre sludge, and some difficulties arose during feeding of these mixed sludges, such as blocking of the feeding system. However, these problems could be overcome.

The nitrogen content of wet sludge (Sludge 2,4,5,6) is similar (approx. $0.5 \%$ ) and much less than in the dried sludge (Sludge 1). This lower nitrogen content in combination with lower feed ratios of wet sludge leads to a smaller increase of the NO emission, Figure 10. Wet sludge 3 has the highest nitrogen content and resulted in the largest increase of NO. In general, the $\mathrm{N}_{2} \mathrm{O}$ emissions are low, Figure 11. The increase in $\mathrm{N}_{2} \mathrm{O}$ due to wet sludge follows a similar pattern as that of $\mathrm{NO}$, largest increase for sludge 3 and much less for the others. The emissions of the two remaining nitrogen species, $\mathrm{NO}_{2}$ and $\mathrm{NH}_{3}$, Figure 12 and 13, are very low and not changing with the sludge feed ratios. The next species of interest is $\mathrm{HCl}$, Figure 14. The largest increase of $\mathrm{HCl}$ was measured in the case of fibre sludge. This increase has no coupling to the higher chlorine content of the sludge, Table 1. Another aspect of the $\mathrm{HCl}$ emission is related to the sludge 4 and 5. Two test series were performed, the only difference being the use of ironaluminiumsulphate (AVR) as precipitation agent in the first test and polyaluminiumchloride (PAC) in the second. This leads to an increase in the chlorine concentration in the sludge with a factor of 5, Table 1 and higher levels of $\mathrm{HCl}$ in the stack. The consequence of changing precipitation agent was not important, though, since the reference level without a chlorine containing precipitation agent is very low. There is also an influence from the alkali metals, potassium $(\mathrm{K})$ and sodium $(\mathrm{Na})$, as indicated in the lower emissions with sludge 3 in spite of higher chlorine content than that from sludge 5 when PAC was used. Table 1 reveals that both $\mathrm{K}$ and $\mathrm{Na}$ are present in higher concentrations in the ash from sludge 3 , and these species can result in the formation of the salts $\mathrm{KCl}$ and $\mathrm{NaCl}$, preventing the chloride from being emitted as $\mathrm{HCl}$.

The $\mathrm{SO}_{2}$ emissions are shown in Figure 15. The high sulphur content of the sludges 4 and 5 correlates well with the large increase of its $\mathrm{SO}_{2}$ emission. The $\mathrm{SO}_{2}$ emissions are very similar in the two test series with sludge 4 and 5 despite the non-sulphur precipitation agent used in the second series. This means that the dominant sulphur source is the wastewater process itself and the choice of precipitation agent is of minor importance when the pulp and paper process produces concentrations of sulphur in the sludge above $2 \%$ on dry basis. The second highest sulphur content is found in sludge 3 . Despite some calcium added with the ash, an increase of the emission cannot be avoided, Figure 15. The influence of natural addition of calcium with the fuel ash is seen for the sludge 2 . The sulphur concentration in the fuel is twice as high as in the fibre sludge (Sludge 6), Table 1, but the emission of $\mathrm{SO}_{2}$ is lower for sludge 2 thanks to the high $\mathrm{Ca} / \mathrm{S}$ molar ratio of 5 . The fibre sludge (Sludge 6) only has a $\mathrm{Ca} / \mathrm{S}$ molar ratio of 1.4. Obviously, the $\mathrm{Ca}$ content in the ash has to be taken into account when discussing the effect of sulphur content in the sludge and the emission of $\mathrm{SO}_{2}$. This aspect favours the use of fluidised beds over grate combustors, since in fluidised bed boilers sulphur can be captured in the combustion process.

In contrast to the dry sludge, the wet sludge does not cause any spikes of $\mathrm{CO}$ and total hydrocarbons in the exiting flue gases. The reason is that the sludge is fed as a cake that is smoothly added into the particle seal of the boiler ((4) Figure $1)$, serving as a pre-combustion chamber, and then further to the main combustion chamber. The dry sludge, on the other hand, is fed into the furnace through the standard fuel chute $((7)$ Figure 1), where fines are entrained by the combustion gas. Wet sludge combustion with wood pellets as base fuel is not only free from spikes of $\mathrm{CO}$ and hydrocarbons but also the average levels of these gases are low, Figures 16,17. The total hydrocarbon concentration is at the lower limit of the analyser $(\approx 1 \mathrm{ppm})$, and the CO concentrations are below $20 \mathrm{mg} / \mathrm{m}^{3}$. Also the concentration of HF was on the limit of the resolution of the FTIR analyser $(\approx 1 \mathrm{ppm})$. As a matter of fact, a slight decrease of the HF concentration recorded may be linked to an unknown cross-sensitivity in the FTIR analyser, Figure 18.

\section{Tests in the Laboratory Unit}

The tests in the laboratory unit were carried out with one fuel at the time. The influence of higher nitrogen, sulphur and chlorine contents in the fuel in relation to the "clean" wood pellets should therefore be more clearly seen than in the corresponding tests in the CFB boiler where no tests with $100 \%$ sludge were carried out. As illustrated in Figures 19-21, many of the trends, seen in the large-scale tests, are confirmed in the laboratory unit: 1) The NOx emission increases when substituting wood pellets with sludge, Figure 19. Sludge 3 with the highest nitrogen content leads to the highest NOx emission also in the laboratory unit. 2) For sulphur the highest 
concentration was found in the sludge 4 and 5, where the two sludges tested gave high and similar sulphur emissions, Figure 20. The influence of changing the precipitation agent in the wastewater cleaning plant was small also in the laboratory unit. There is almost no difference in $\mathrm{SO}_{2}$ emissions and a measurable increase of the $\mathrm{HCl}$ emission with PAC produced sludge but from a low level, Figure 21.

\section{CONCLUSIONS}

The following conclusions can be made:

- Six pulp\&paper mill sludges of various origin and type have been burned together with wood pellets in a CFB boiler. The combustion was carried out without problem.

- Feeding of the sludge into the furnace could be a major problem in connection to combustion, but such problems can be avoided using suitable fuel feed systems.

- A sludge pump is one possibility to feed mechanical dewatered sludge, especially if the sludge is produced in a biological cleaning step, but such a pump does not work properly with sludge that mainly consists of fibres.

- Pre-dried sludge may give rise to spikes of $\mathrm{CO}$ and hydrocarbon emissions if the fuel contains too large a fraction of fines. In such cases attention has to be paid to the method of fuel feeding.

- The content of sulphur, nitrogen and chlorine in the sludge influences the emissions markedly when sludge is cocombusted with a "clean" base fuel, such as wood pellets.

- All sludges tested contain higher concentrations of nitrogen than the wood pellets. The NO emission dominates among the four nitrogen species measured $\left(\mathrm{NO}, \mathrm{NO}_{2}, \mathrm{~N}_{2} \mathrm{O}\right.$, $\mathrm{NH}_{3}$ ) and increases with the ratio of sludge.

- All sludges contain higher concentrations of sulphur than wood pellets. This leads to higher emissions of $\mathrm{SO}_{2}$ at higher feed ratios of sludge. The calcium content in the sludge may mitigate this effect, as demonstrated by sludge 2 . In most cases this will not be sufficient to prevent the $\mathrm{SO}_{2}$ emission to reach a level above the legalisation level, and active actions like lime addition to the fluidized bed or hydrated lime to a bag filter are required.

- Substitution of ironaluminiumsulphate (AVR) as precipitation agent with a species not containing sulphur like polyaluminiumchloride (PAC) did not significantly change the sulphur content of the sludge.

- The use of PAC in sludge 5 increases the chlorine content of the sludge. This has a marginal effect on the $\mathrm{HCl}$ emission.

- Some aspects of substitution of wood pellets with sludge were confirmed in a laboratory-scale reactor.

\section{ACKNOWLEDGMENTS}

This work was financially support mainly from VärmeForsk Service AB and the Swedish Energy Administration (STEM). Additional support was received from Kemira Kemi, Eka Chemicals, Fortum, Kvaerner Pulping, Econova Biotech, Nordic Paper, Stora Enso Packaging Board, Holmen Iggesund Paperboard, M-Real. The practical performance of the tests was carried out with heavy support from the operating staff of Akademiska Hus $\mathrm{AB}$ and researchers belonging to the Department of Energy Conversion, which is gratefully acknowledged.

\section{REFERENCES}

1. Anthony E. J., Preto F., 1993, "The Technical, Environmental and Economic Feasibility of Recovering Energy from Paper Mill Residual fiber,“ Proceedings, $12^{\mathrm{th}}$ International Conference on Fluidized Bed Combustion, L. Rubov and G. Commonwelth, eds., American Society of Mechanical Engineers, New York, Vol. 1, pp 239-247.

2. Louhimo J. T., 1993 "Combustion of Pulp \& Paper Mill Sludges and Biomass in BFB," Proceedings, $12^{\text {th }}$ International Conference on Fluidized Bed Combustion, L. Rubov and G. Commonwelth, eds., American Society of Mechanical Engineers, New York, Vol. 1, pp 249-264.

3. Dixit V. B., Mongeon R. K., Reicker E. L., 1993, "Special Emission Measurements on Riley Stoker's Advanced CFB Pilot Facility Co-Firing Non-Recyclable De-Inking Paper Fiber and High Sulfur Eastern Bituminous Coal," Proceedings, $12^{\text {th }}$ International Conference on Fluidized Bed Combustion, L. Rubov and G. Commonwelth, eds., American Society of Mechanical Engineers, New York, Vol. 1, pp 231-237.

4. Li X., Jiang X., Yan J., Zeng T., Chi Y., Yang J., Huang G., Pan G., Ni M., Cen K., 1997 "Experimental Study and Design Considerations for Co-Firing Paper Mill Sludge in a CFB Boiler," Proceedings, $14^{\text {th }}$ International Conference on Fluidized Bed Combustion, F.D.S. Preto, ed., American Society of Mechanical Engineers, New York, Vol. 1, pp 159-164.

5. Zhao C., Chen X., Huang C. Lan J., Duan Y., Cui G., Wang W., 1999 "Fluidization and Incineration of Pulp and Paper Mill sludge in BFB," Proceedings, $15^{\text {th }}$ International Conference on Fluidized Bed Combustion, R. B. Reuther, ed., American Society of Mechanical Engineers, New York, FBC99-0086.

6. Torii I., Tagashira, K., Myouyou K, Yokoshiki T., Shirahata T., 2001 "Development of Paper Sludge and Coal Co-Fired Bubbling Fluidized Bed Boiler," Proceedings, $16^{\text {th }}$ International Conference on Fluidized Bed Combustion, D. W. Geiling, ed., American Society of Mechanical Engineers, New York, FBC01-0179.

7. Anderl H., Kaufmann K., 2001 "RDF and Sludge Incineration in a $110 \mathrm{MW}_{\text {th }}$ CFB Boiler RVL Lenzing," Proceedings, $16^{\text {th }}$ International Conference on Fluidized Bed Combustion, D. W. Geiling, ed., American Society of Mechanical Engineers, New York, FBC01-0194.

8. Åmand L.-E., Leckner B., Hansson L., Norrlöw O., 2003, "Co-Combustion of Municipal Sludge with Wood/Coal in CFB - Enrichment of Phosphorous and Cadmium in Ashes," Paper submitted for presentation on the $17^{\text {th }}$ International Conference on Fluidized Bed Combustion, , S. V. Prisupati, ed., American Society of Mechanical Engineers, New York, FBC03-0098. 
TABLE 1. Origin, type and properties of the pulp and paper sludges.

\begin{tabular}{|c|c|c|c|c|c|c|c|}
\hline $\begin{array}{l}\text { Sludge } \\
\text { Type of sludge } \\
\text { Precipitation agent }\end{array}$ & $\begin{array}{c}\text { Sludge 1 } \\
\text { Dried, } F_{(1)}, B_{(3)}\end{array}$ & $\begin{array}{c}\text { Sludge 2 } \\
\text { Wet, } F_{(1)}, C_{(2)}\end{array}$ & $\begin{array}{c}\text { Sludge 3 } \\
\text { Wet, } F_{(1)}, B_{(3)}\end{array}$ & $\begin{array}{c}\text { Sludge 4 } \\
\text { Wet, } F_{(1)}, C_{(2)} \\
\operatorname{AVR}_{(4)} \\
\end{array}$ & $\begin{array}{c}\text { Sludge 5 } \\
\text { Wet, } \mathrm{F}_{(1)}, \mathrm{C}_{(2)} \\
\mathrm{PAC}_{(5)} \\
\end{array}$ & $\begin{array}{l}\text { Sludge } 6 \\
\text { Wet, } F_{(1)} \text {, }\end{array}$ & $\begin{array}{l}\text { Wood } \\
\text { pellets }\end{array}$ \\
\hline \multicolumn{8}{|l|}{ Proximate analysis } \\
\hline Water (wt-\%, raw) & 26.2 & 73.4 & 82.2 & 77.6 & 76.7 & 72.4 & 8.3 \\
\hline Ash (wt-\%, dry) & 24.8 & 21.0 & 15.1 & 12.3 & 12.7 & 2.3 & 0.45 \\
\hline Combustibles (wt-\%, dry) & 56.6 & 21.0 & 15.2 & 19.6 & 20.4 & 27.0 & 91.2 \\
\hline Volatiles (wt- $\%$, daf) & 77.4 & 87.0 & 82.9 & 72.1 & 72.7 & 81.8 & 81.8 \\
\hline \multicolumn{8}{|l|}{ Ultimate analysis (wt- $\%$, daf) } \\
\hline C & 55.0 & 48.6 & 48.8 & 52.4 & 51.8 & 52.2 & 50.3 \\
\hline $\mathrm{H}$ & 6.2 & 6.6 & 6.5 & 6.3 & 6.4 & 6.5 & 6.1 \\
\hline $\mathrm{O}$ & 36.3 & 43.8 & 40.0 & 38.3 & 38.8 & 40.7 & 43.5 \\
\hline S & 1.10 & 0.58 & 1.42 & 2.41 & 2.28 & 0.26 & 0.01 \\
\hline $\mathrm{N}$ & 1.34 & 0.48 & 3.31 & 0.55 & 0.62 & 0.44 & 0.09 \\
\hline $\mathrm{Cl}$ & 0.08 & 0.03 & 0.02 & 0.009 & 0.05 & 0.007 & 0.01 \\
\hline \multicolumn{8}{|l|}{ Lower heating value (MJ/kg) } \\
\hline $\mathrm{Hu}, \mathrm{daf}_{(6)}$ & 19.99 & 16.72 & 18.34 & 19.26 & 20.09 & 19.57 & 18.81 \\
\hline $\mathrm{Hu}, \operatorname{raw}_{(7)}$ & 9.68 & 1.6 & 0.73 & 1.85 & 2.18 & 3.47 & 16.90 \\
\hline \multicolumn{8}{|l|}{ Ash analysis (g/kg dry ash) } \\
\hline $\mathrm{K}$ & 9.4 & 3.5 & 17.7 & 2.8 & 6.3 & 9.5 & 82 \\
\hline $\mathrm{Na}$ & 8.6 & 7.9 & 32.6 & 8.4 & 11.7 & 108 & 6.7 \\
\hline Al & 125 & 185 & 125 & 263 & 317 & 84.1 & 12.2 \\
\hline $\mathrm{Si}$ & 239 & 86.8 & 100 & 110 & 64.9 & 116 & 79.7 \\
\hline $\mathrm{Fe}$ & 27.4 & 25.1 & 96.4 & 20.1 & 8.6 & 23.3 & 20.9 \\
\hline $\mathrm{Ca}$ & 35.9 & 151 & 44.3 & 7 & 7.1 & 94.6 & 164 \\
\hline $\mathrm{Mg}$ & 14.7 & 4.4 & 38.6 & 20.6 & 21.7 & 10.9 & 26.4 \\
\hline P & 5.3 & 4.4 & 25.7 & 3.4 & 3.6 & 14.2 & 12.7 \\
\hline $\mathrm{Ti}$ & 19.8 & 8.8 & 1.2 & 28.9 & 18.9 & 4.8 & 0.7 \\
\hline $\mathrm{Ba}$ & 0.4 & 0.2 & 1.7 & 0.4 & 0.4 & 1.2 & 2.4 \\
\hline
\end{tabular}

$(1)=$ fibre sludge, $(2)=$ chemical precipitated sludge, (3)= biological sludge, (4)= Ironaluminiumsulphate, (5)= Polyaluminiumchloride, (6)= dry and ash free, (7)=as received

TABLE 2. Operating conditions for the tests with pre-dried sludge and pure wood pellets

\begin{tabular}{|c|c|c|c|c|}
\hline $\begin{array}{l}\text { Sludge } \\
\text { Type of sludge } \\
\text { Test number }\end{array}$ & $\begin{array}{c}\text { Sludge 1 } \\
\text { Dried, } \mathrm{F}_{(1)}, \mathrm{C}_{(2)} \\
2\end{array}$ & $\begin{array}{c}\text { Sludge } 1 \\
\text { Dried, } \mathrm{F}_{(1)}, \mathrm{C}_{(2)} \\
1\end{array}$ & $\begin{array}{c}\text { Sludge } 1 \\
\text { Dried, } \mathrm{F}_{(1)}, \mathrm{C}_{(2)} \\
3\end{array}$ & $\begin{array}{c}\text { Wood } \\
\text { pellets } \\
1\end{array}$ \\
\hline waste fraction $_{(3)}, \%$ & 13.4 & 25.3 & 52.9 & 0.0 \\
\hline load, $M W_{\text {th }}$ & 6.3 & 6.2 & 6.1 & 6.7 \\
\hline bed temp., ${ }^{\circ} \mathrm{C}$ (bottom) & 851 & 851 & 851 & 849 \\
\hline $\begin{array}{l}\text { bed temp., }{ }^{\circ} \mathrm{C} \text { (top) } \\
\text { exit temp. of after }\end{array}$ & 860 & 854 & 857 & 861 \\
\hline burning chamber, ${ }^{\circ} \mathrm{C}$ & 828 & 825 & 829 & 865 \\
\hline $\begin{array}{l}\text { total riser pressure drop, } \mathrm{kPa} \\
\text { Calcium addition }\end{array}$ & 6.4 & 6.5 & 6.6 & 6.3 \\
\hline molar ratio $\mathrm{Ca} / \mathrm{S}$ & 0.00 & 0.00 & 0.00 & 0.00 \\
\hline $\mathrm{Ca} / \mathrm{S}$ with $\mathrm{Ca}$ in fuel included & 1.44 & 1.01 & 0.76 & 2.81 \\
\hline $\begin{array}{l}\text { excess air ratio } \\
\text { primary air flow/ }\end{array}$ & 1.26 & 1.28 & 1.25 & 1.19 \\
\hline total air flow, \% & 59 & 58 & 59 & 55 \\
\hline $\begin{array}{l}\text { superficial flue gas velocity } \\
\text { at top of riser } U_{\text {top }}, \mathrm{m} / \mathrm{s}\end{array}$ & 5.3 & 5.4 & 5.5 & 5.3 \\
\hline
\end{tabular}

$(1)=$ fibre sludge, $(2)=$ chemical precipitated sludge, $(3)=$ dry matter(waste)/dry matter (mixture) 
TABLE 3. Operating conditions for the tests with mechanical dewatered sludge.

\begin{tabular}{|c|c|c|c|c|c|c|c|c|c|c|}
\hline $\begin{array}{l}\text { Sludge } \\
\text { Type of sludge } \\
\text { Precipitation agent } \\
\text { Test number }\end{array}$ & \begin{tabular}{|c|} 
Sludge 2 \\
Wet, $F_{(1)}, C_{(2)}$ \\
1
\end{tabular} & \begin{tabular}{|c|} 
Sludge 2 \\
Wet, $F_{(1)}, C_{(2)}$ \\
21
\end{tabular} & $\begin{array}{c}\text { Sludge 2 } \\
\text { Wet, } F_{(1)}, C_{(2)} \\
22\end{array}$ & $\begin{array}{c}\text { Sludge 3 } \\
\text { Wet, } F_{(1)}, B_{(3)} \\
1\end{array}$ & $\begin{array}{c}\text { Sludge 3 } \\
\begin{array}{c}\text { Wet, } F_{(1)}, B_{(3)} \\
22\end{array}\end{array}$ & $\begin{array}{c}\text { Sludge 4 } \\
\text { Wet, } F_{(1)}, C_{(2)} \\
\operatorname{AVR}_{(4)} \\
1\end{array}$ & \begin{tabular}{|c|} 
Sludge 4 \\
Wet, $F_{(1)}, C_{(2)}$ \\
$\operatorname{AVR}_{(4)}$ \\
2
\end{tabular} & \begin{tabular}{|c|} 
Sludge 5 \\
Wet, $F_{(1)}, C_{(2)}$ \\
$\operatorname{PAC}_{(5)}$ \\
3
\end{tabular} & $\begin{array}{c}\text { Sludge 5 } \\
{\text { Wet, } \mathrm{F}_{(1)}, \mathrm{C}_{(2)}}_{\mathrm{PAC}_{(5)}} \\
4\end{array}$ & \begin{tabular}{|c} 
Sludge 6 \\
Wet, $F_{(1)}$ \\
1
\end{tabular} \\
\hline waste fraction $_{(6)}, \%$ & 14.6 & 7.9 & 8.0 & 10.3 & 5.8 & 12.2 & 6.0 & 14.8 & 7.6 & 16.0 \\
\hline load, $M W_{\text {th }}$ & 6.5 & 6.3 & 6.3 & 6.2 & 6.2 & 6.5 & 6.6 & 5.9 & 6.0 & 6.3 \\
\hline bed temp., ${ }^{\circ} \mathrm{C}$ (bottom) & 853 & 850 & 848 & 847 & 850 & 847 & 847 & 848 & 850 & 849 \\
\hline $\begin{array}{l}\text { bed temp., }{ }^{\circ} \mathrm{C} \text { (top) } \\
\text { exit temp. of after }\end{array}$ & 871 & 859 & 847 & 872 & 871 & 873 & 867 & 859 & 856 & 859 \\
\hline burning chamber, ${ }^{\circ} \mathrm{C}$ & 880 & 858 & 859 & 835 & 832 & 859 & 869 & 827 & 815 & 878 \\
\hline $\begin{array}{l}\text { total riser pressure drop, } \mathrm{kPa} \\
\text { Calcium addition }\end{array}$ & 6.3 & 6.3 & 6.4 & 6.4 & 6.3 & 6.5 & 6.2 & 6.2 & 6.2 & 6.3 \\
\hline molar ratio $\mathrm{Ca} / \mathrm{S}$ & 0.00 & 0.00 & 0.00 & 0.00 & 0.00 & 0.00 & 0.00 & 0.00 & 0.00 & 0.00 \\
\hline $\mathrm{Ca} / \mathrm{S}$ with $\mathrm{Ca}$ in fuel included & 5.16 & 5.14 & 4.97 & 0.70 & 1.18 & 0.25 & 0.25 & 0.24 & 0.42 & 1.40 \\
\hline $\begin{array}{l}\text { excess air ratio } \\
\text { primary air flow/ }\end{array}$ & 1.23 & 1.21 & 1.20 & 1.22 & 1.24 & 1.19 & 1.21 & 1.24 & 1.25 & 1.21 \\
\hline $\begin{array}{l}\text { total air flow, } \% \\
\text { superficial flue gas velocity }\end{array}$ & 57 & 58 & 58 & 59 & 58 & 58 & 49 & 58 & 59 & 58 \\
\hline at top of riser $U_{\text {top }}, \mathrm{m} / \mathrm{s}$ & 5.7 & 5.4 & 5.2 & 5.2 & 4.8 & 5.6 & 6.0 & 5.1 & 5.0 & 5.7 \\
\hline
\end{tabular}

$(1)=$ fibre sludge, (2)= chemical precipitated sludge, (3)= biological sludge, (4)= Ironaluminiumsulphate, (5)= Polyaluminiumchloride, (6)= dry matter(waste)/dry matter (mixture) 


\section{FIGURES}

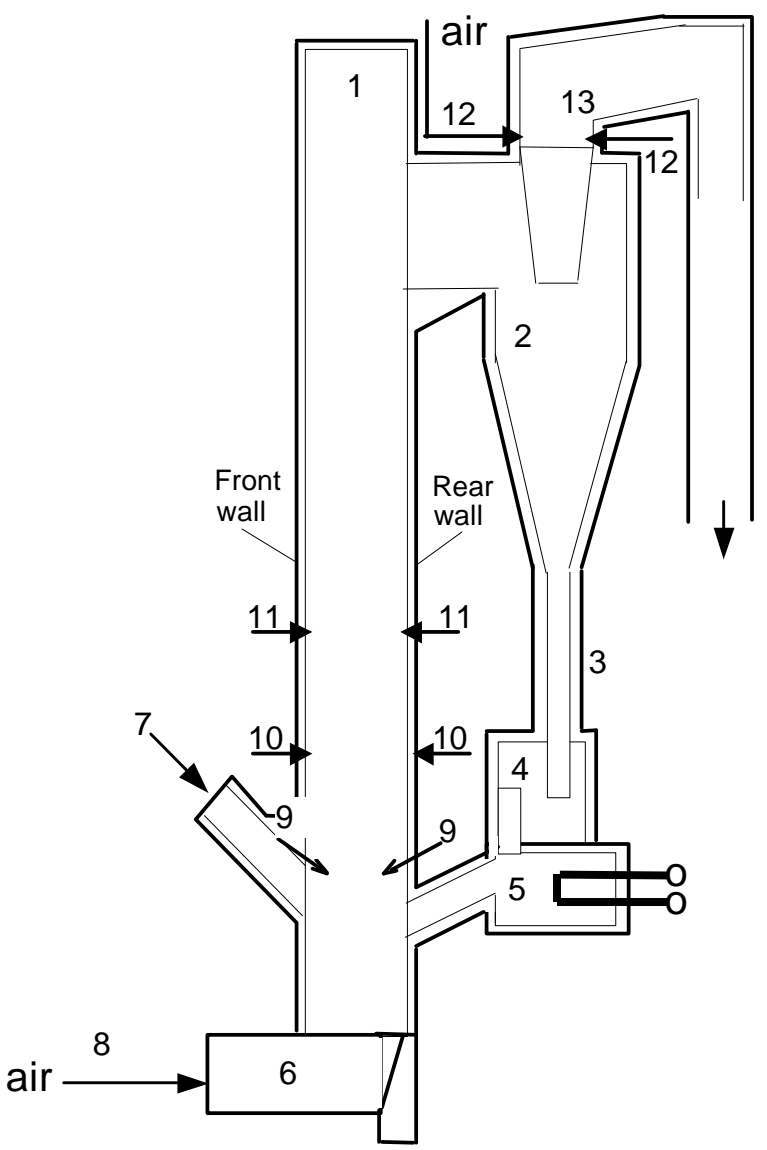

Figure 1. The 12-MW $\mathrm{MW}_{\text {th }}$ CFB boiler at Chalmers University of Technology. (1) combustion chamber, (2) cyclone, (3) particle return leg, (4) particle seal, (5) heat exchanger, (6) windbox, (7) fuel feed chute, (8) primary air supply, (9) secondary air to 2.1 meter, (10) secondary air to 3.7 meter, (11) secondary air to 5.4 meter, (12) secondary air addition after cyclone, (13) exit duct cyclone.

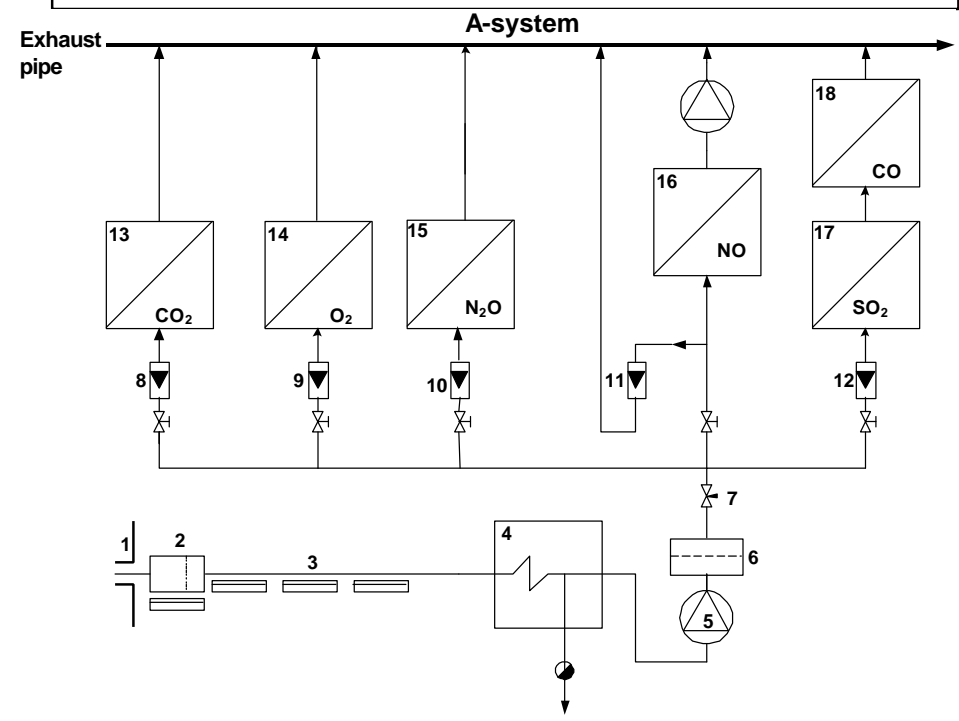

Figure 3. Gas analysis system A used for analysis of flue gas in the stack. (1) gas sampling probe; (2) heated ceramic filter; (3) heated gas sampling line; (4) moisture removal; (5) gas sampling pump; (6) safety filter; (7) mass flow controller, total flow; (8-12) individual volumetric flow controllers; (13) $\mathrm{CO}_{2}$ analyser; (14) $\mathrm{O}_{2}$ analyser; (15) $\mathrm{N}_{2} \mathrm{O}$ analyser; (16) NO analyser; (17) $\mathrm{SO}_{2}$ analyser (18) $\mathrm{CO}$ analyser

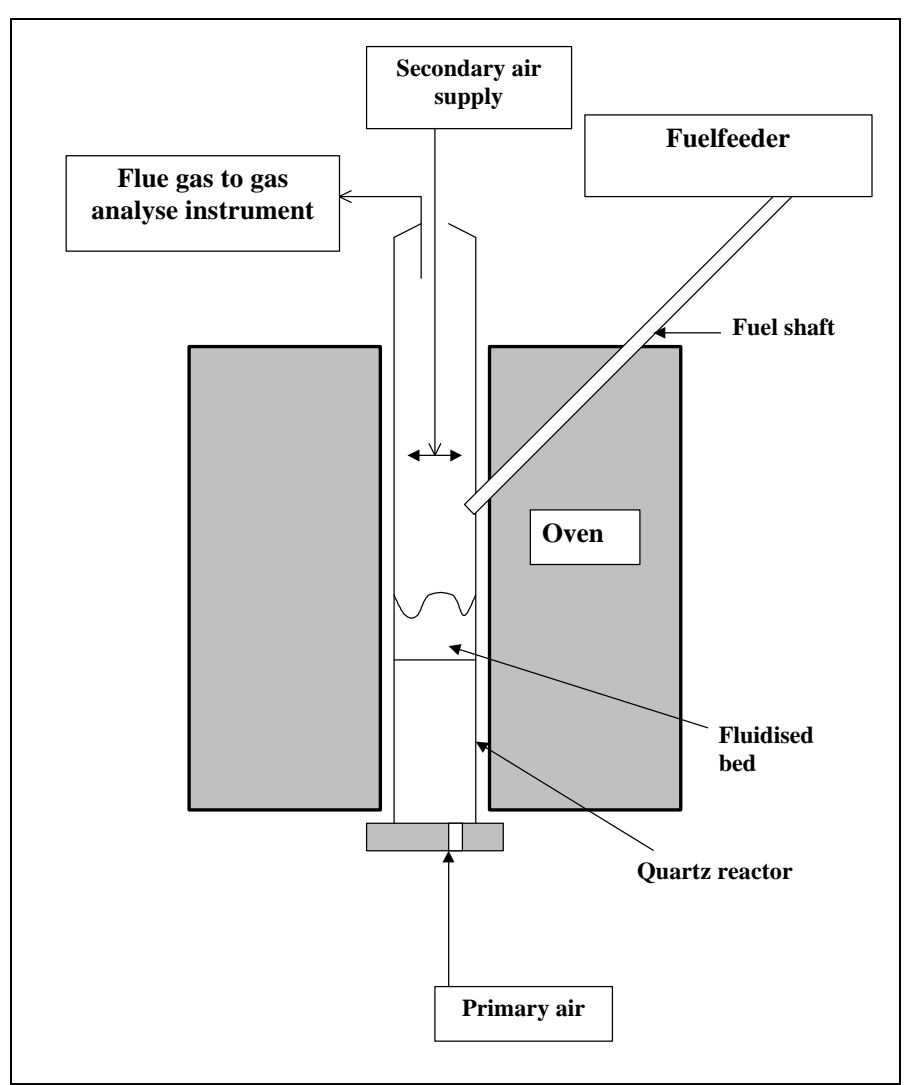

Figure 2. The laboratory reactor at SP, Swedish National Testing and Research Institute.

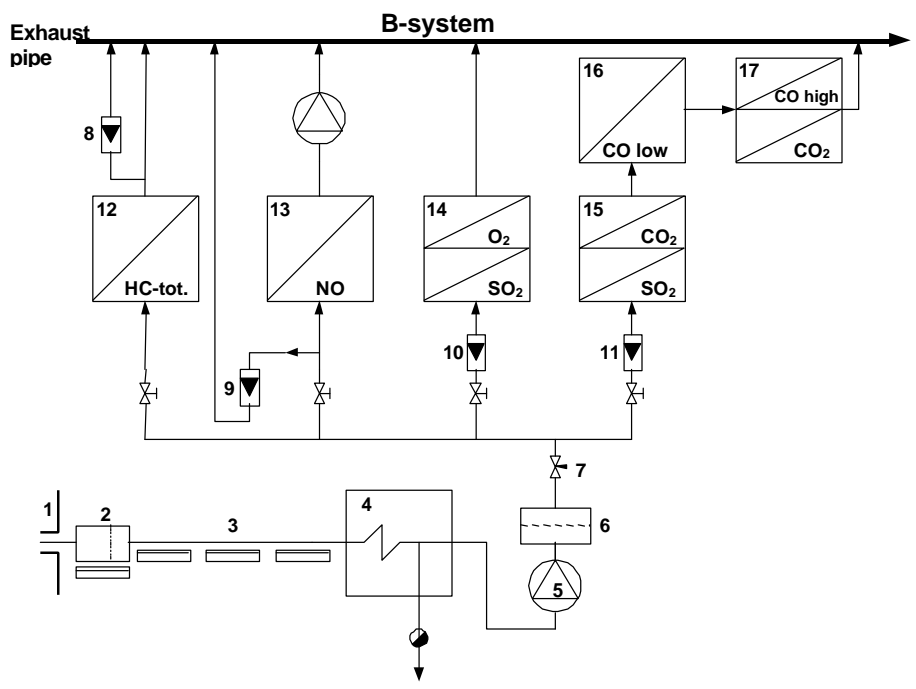

Figure 4. Gas analysis system B normally used for analysis of flue gases from the combustion chamber (1) gas sampling probe; (2) heated ceramic filter; (3) heated gas sampling line; (4) moisture removal; (5) gas sampling pump; (6) safety filter; (7) total mass flow controller; (8-11) individual volumetric flow controllers; (12) HC-tot. analyser; (13) NO analyser; (14) $\mathrm{SO}_{2}$ and $\mathrm{O}_{2}$ analyser; (15) $\mathrm{SO}_{2}$ and $\mathrm{CO}$ analyser; (16) CO-low analyser; (17) $\mathrm{CO}_{2}$ and CO-high analyser 
Exhaust

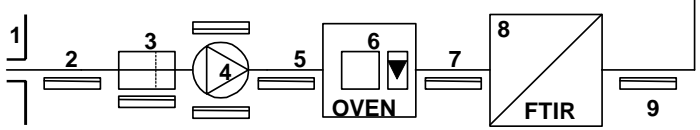

Figure 5. Gas analysis system (FTIR) used for analysis of flue gases from the combustion chamber (1) gas sampling probe with ceramic filter; (2), (5), (7), (9) heated gas sampling line; (3) heated ceramic filter; (4) heated gas sampling pump;(6) oven with filter and volumetric flow controller; (8) Fourier transformed infra-red analyzer.

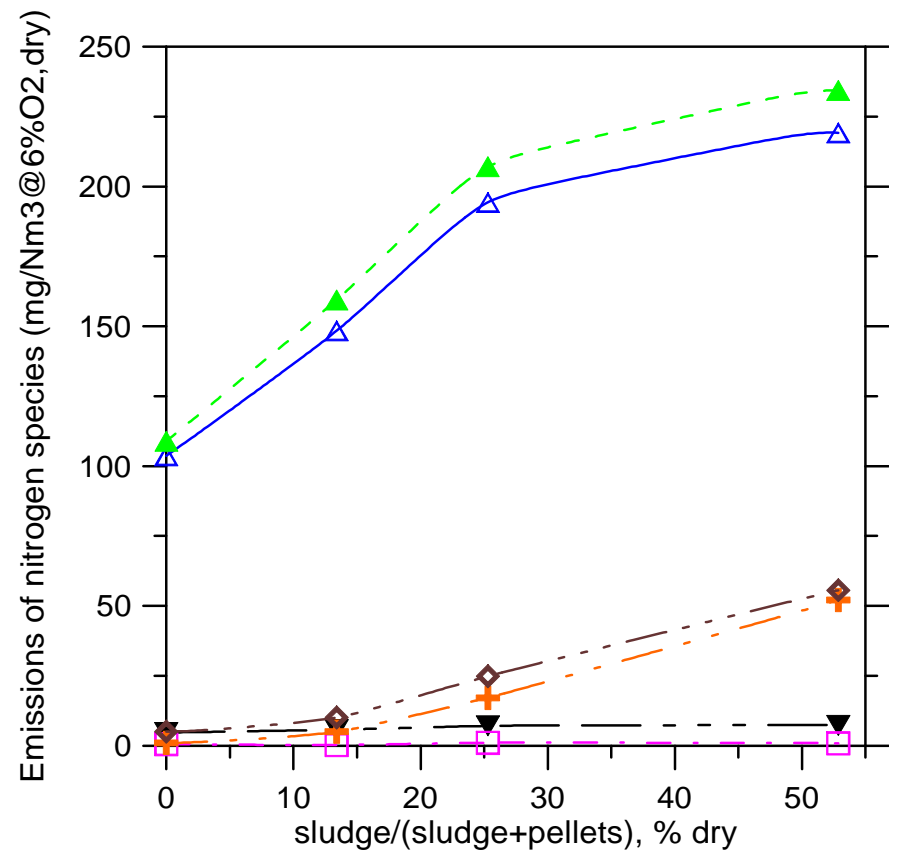

Figure 6. Influence of co-combustion of dry pulp and paper sludge (Sludge 1) with wood pellets on the emissions of nitrogen compounds. $\mathrm{NO}$ and $\mathrm{NO}_{2}$ emissions expressed as $\mathrm{mg} \mathrm{NO}_{2} / \mathrm{Nm}^{3} @ 6 \% \mathrm{O}_{2}$, dry

$\triangle \mathrm{NO}$ chemiluminescence, $\triangle \mathrm{NO}$ FTIR, $\nabla \mathrm{NO}_{2}$ FTIR

$\square \mathrm{NH}_{3}$ FTIR $+\mathrm{N}_{2} \mathrm{O}$ on-line IR $\diamond \mathrm{N}_{2} \mathrm{O}$ FTIR

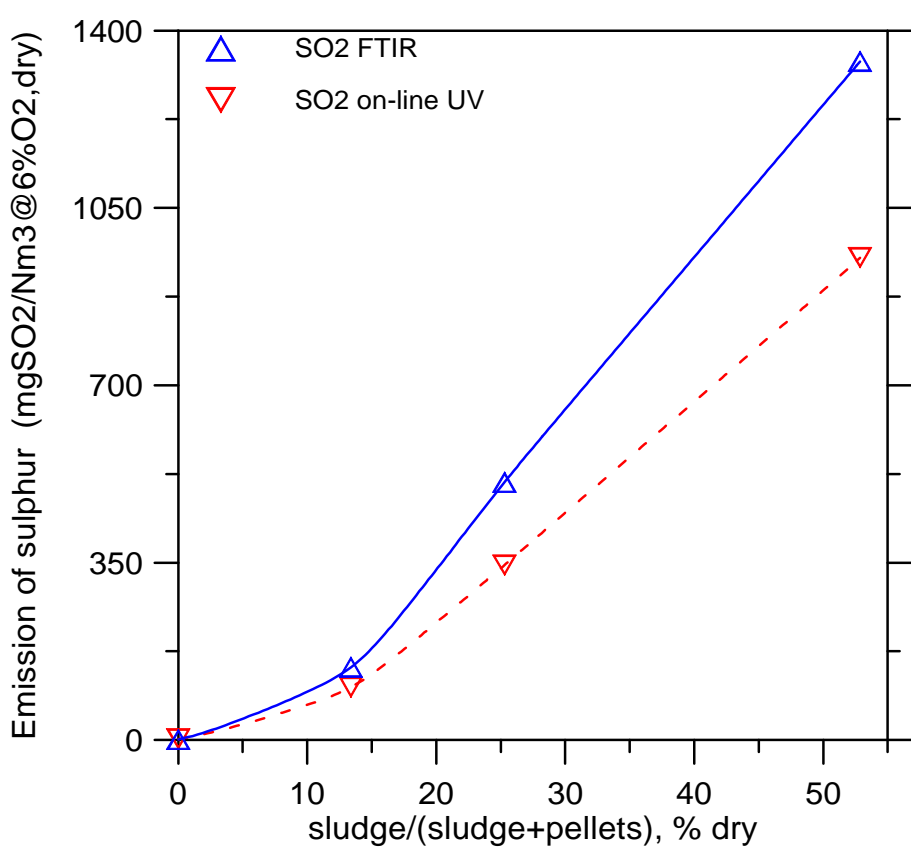

Figure 7. Influence of co-combustion of dry pulp and paper sludge (Sludge 1) with wood pellets on the emission of $\mathrm{SO}_{2}$.

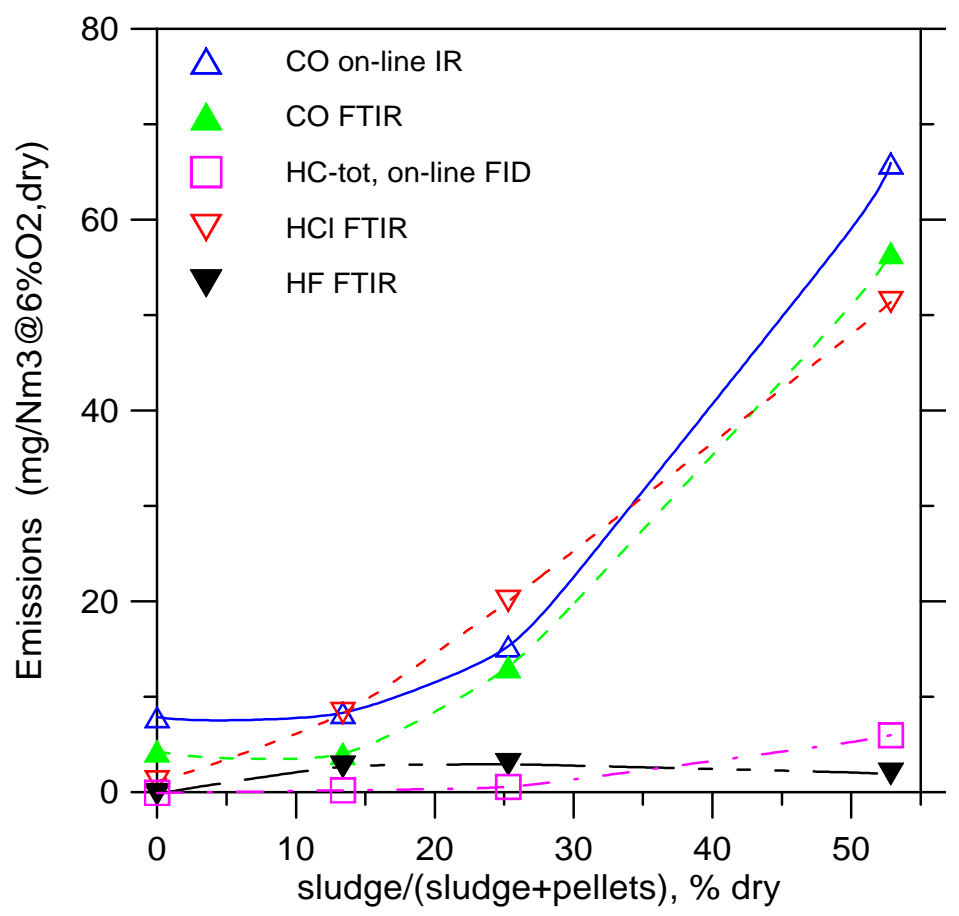

Figure 8. Influence of co-combustion of dry pulp and paper sludge (Sludge 1) with wood pellets on the emissions of $\mathrm{CO}$, total hydrocarbons (HC-tot.), $\mathrm{HCl}$ and $\mathrm{HF}$. 


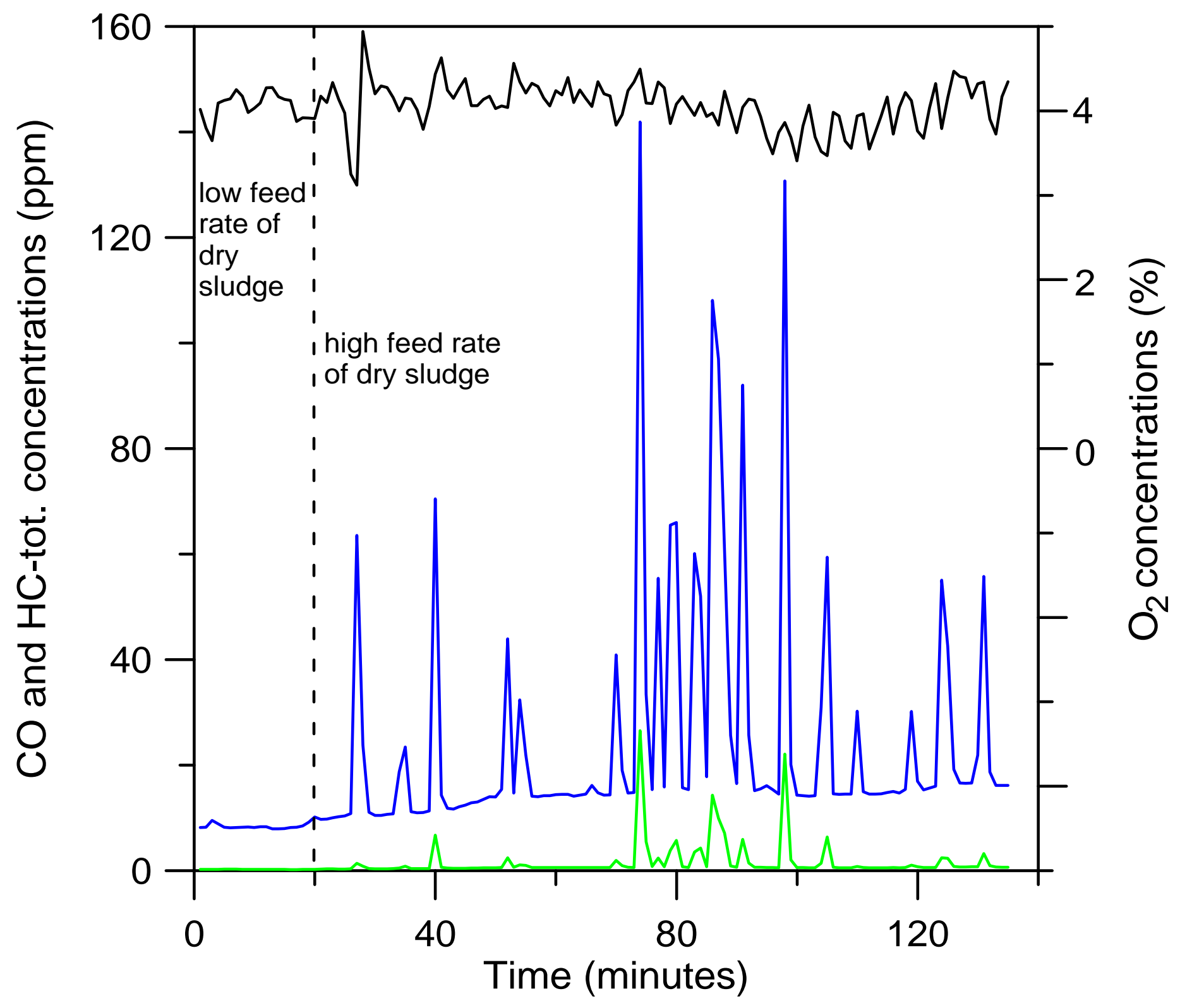

Figure 9. Influence of the increase (at $t=20$ minutes) of the ratio of dry pulp and paper sludge on the emissions of $C O$ (blue) and total hydrocarbons (green). Black: oxygen concentrations 


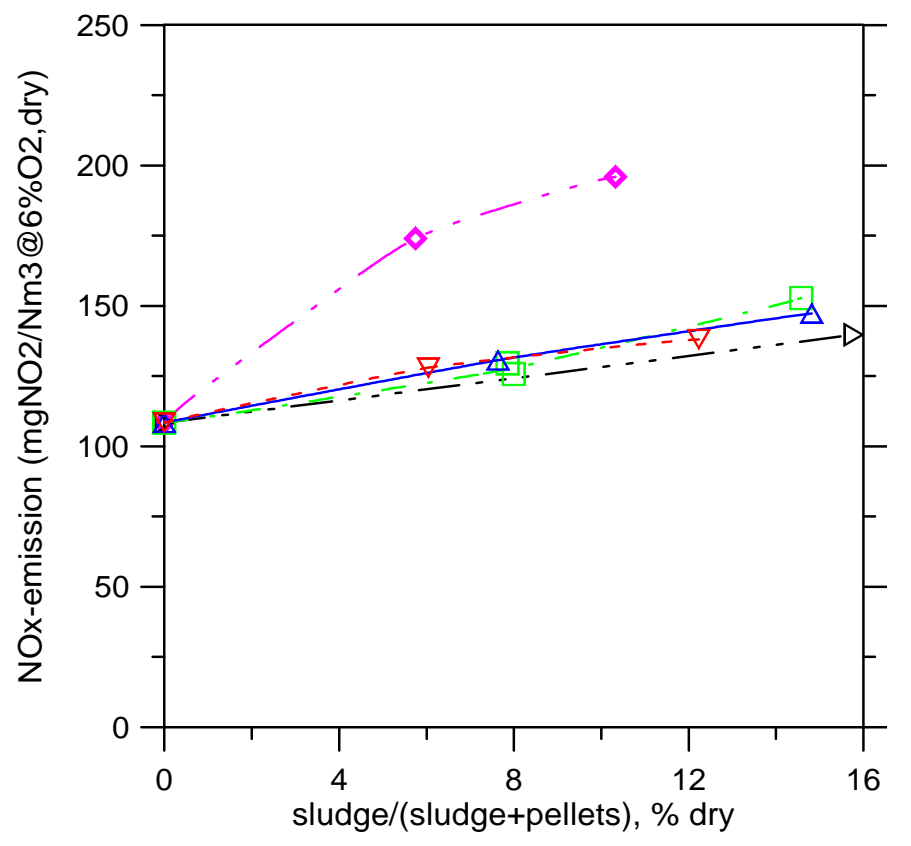

Figure 10. Influence of co-combustion of mechanically dewatered pulp and paper sludge with wood pellets on the emissions of NOx . $\square$ Sludge $2, \diamond$ Sludge $3, \nabla$ Sludge 4 (AVR), $\triangle$ Sludge 5 (PAC), $\triangleright$ Sludge 6

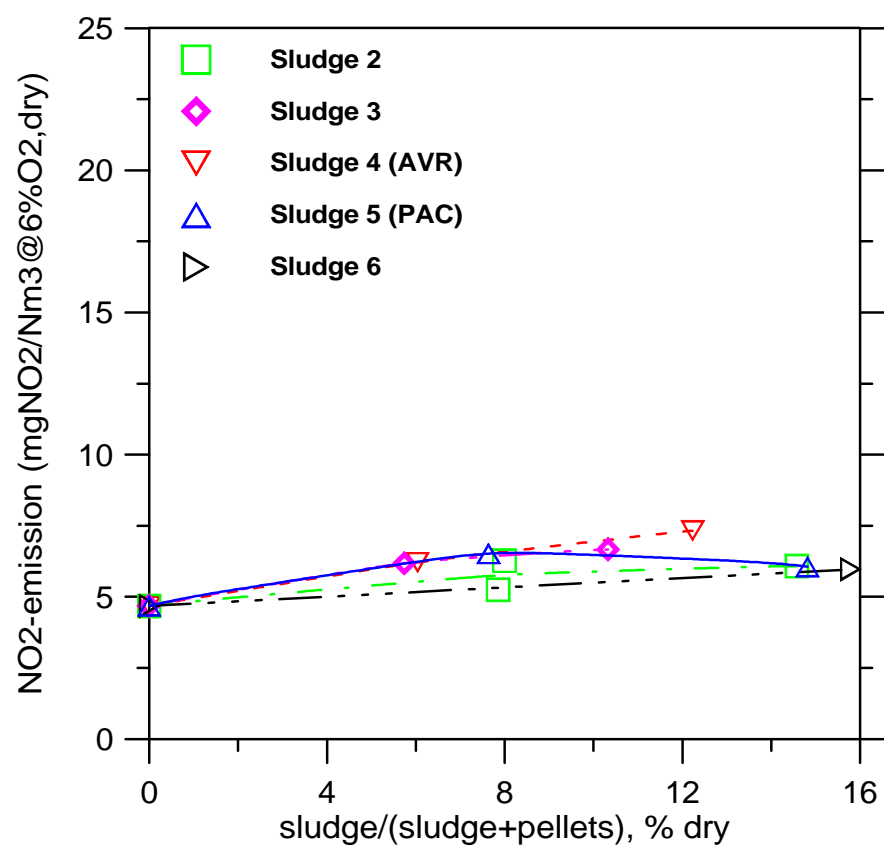

Figure 12. Influence of co-combustion of mechanically dewatered pulp and paper sludge with wood pellets on the emissions of $\mathrm{NO}_{2}$.

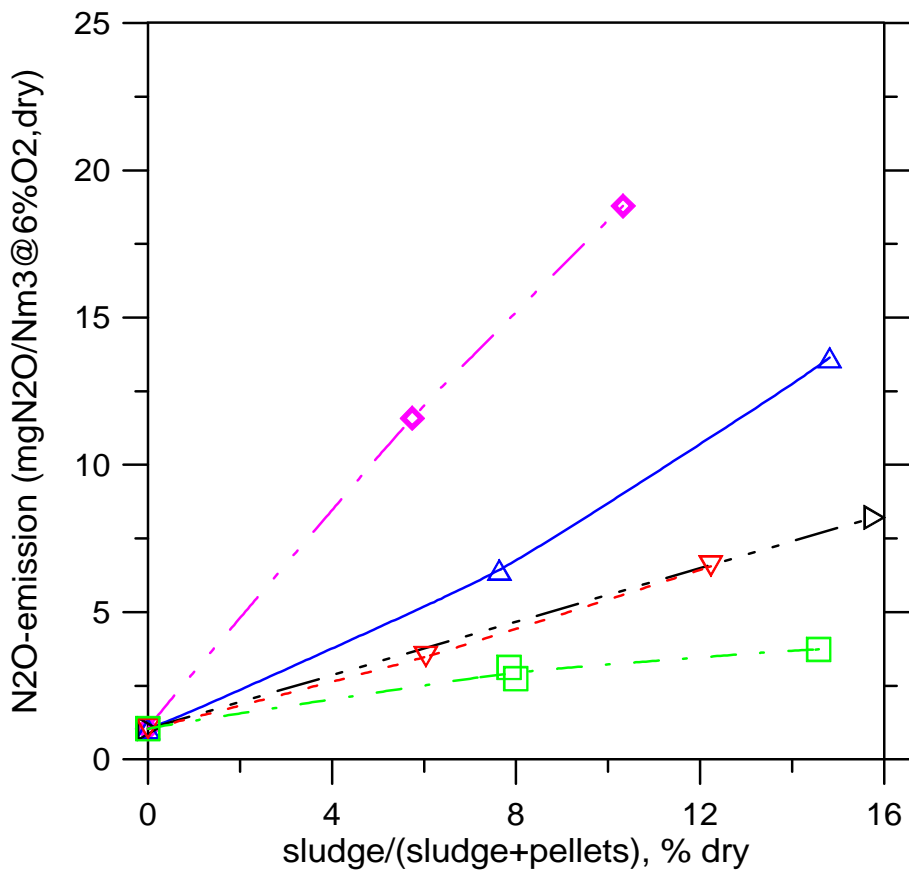

Figure 11. Influence of co-combustion of mechanically dewatered pulp and paper sludge with wood pellets on the emissions of $\mathrm{N}_{2} \mathrm{O}$. $\square$ Sludge $2, \diamond$ Sludge $3, \nabla$ Sludge 4 (AVR), $\triangle$ Sludge 5 (PAC), $\triangleright$ Sludge 6

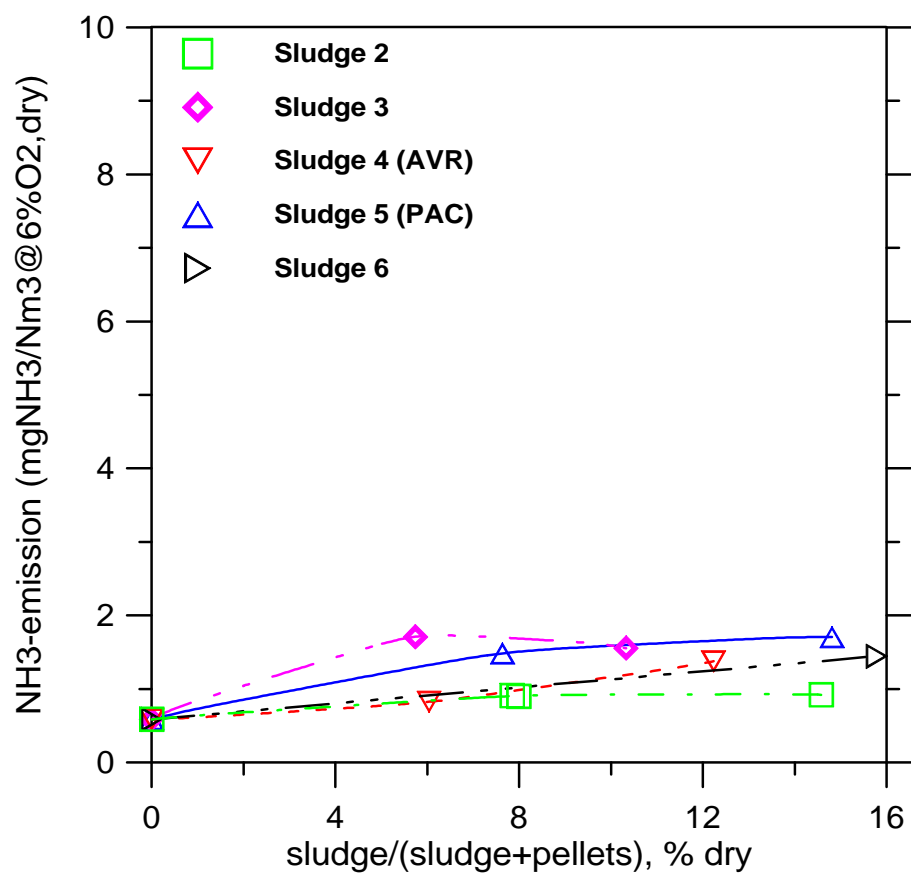

Figure 13. Influence of co-combustion of mechanically dewatered pulp and paper sludge with wood pellets on the emissions of $\mathrm{NH}_{3}$. 


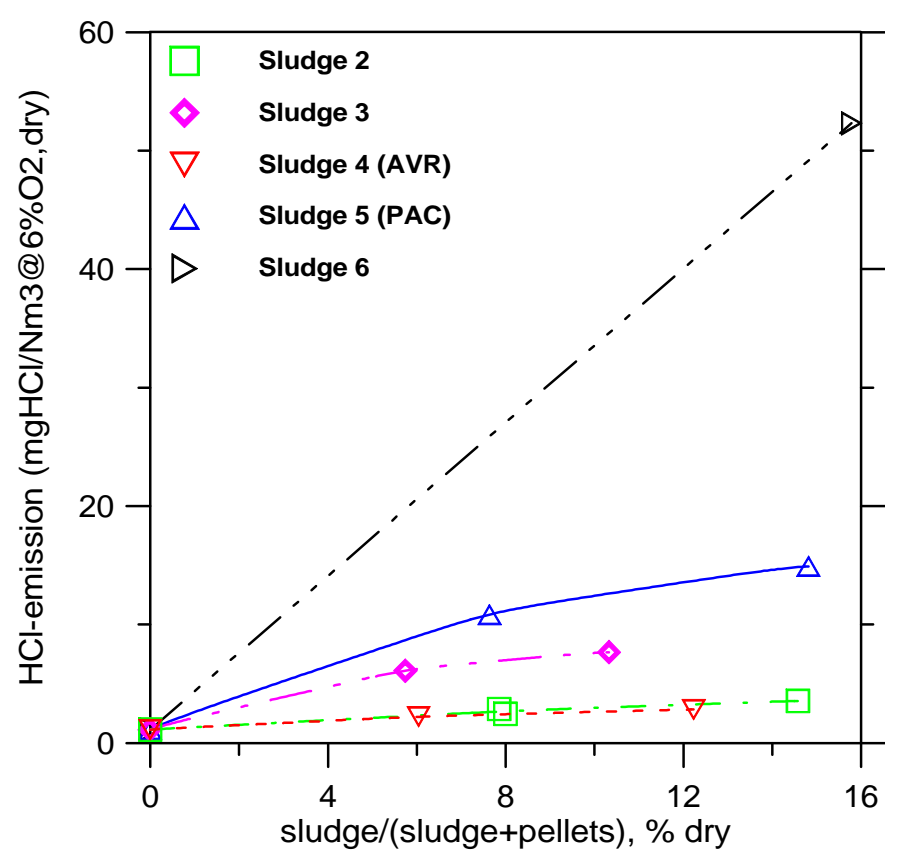

Figure 14. Influence of co-combustion of mechanically dewatered pulp and paper sludge with wood pellets on the emissions of $\mathrm{HCl}$.

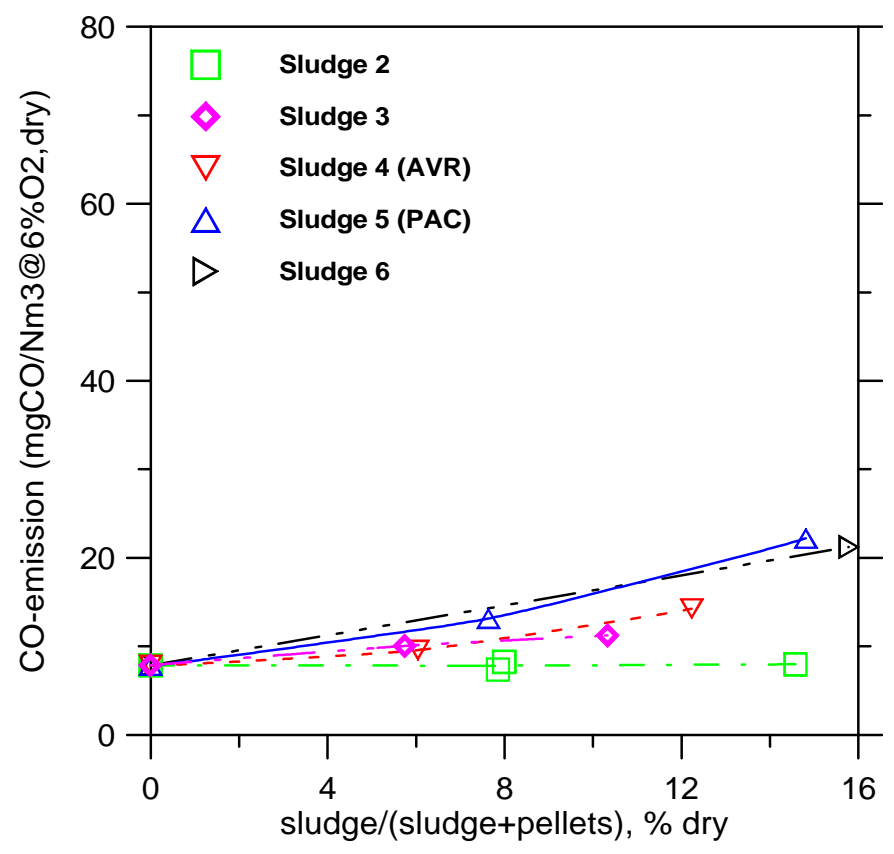

Figure 16. Influence of co-combustion of mechanically dewatered pulp and paper sludge with wood pellets on the emissions of $\mathrm{CO}$.

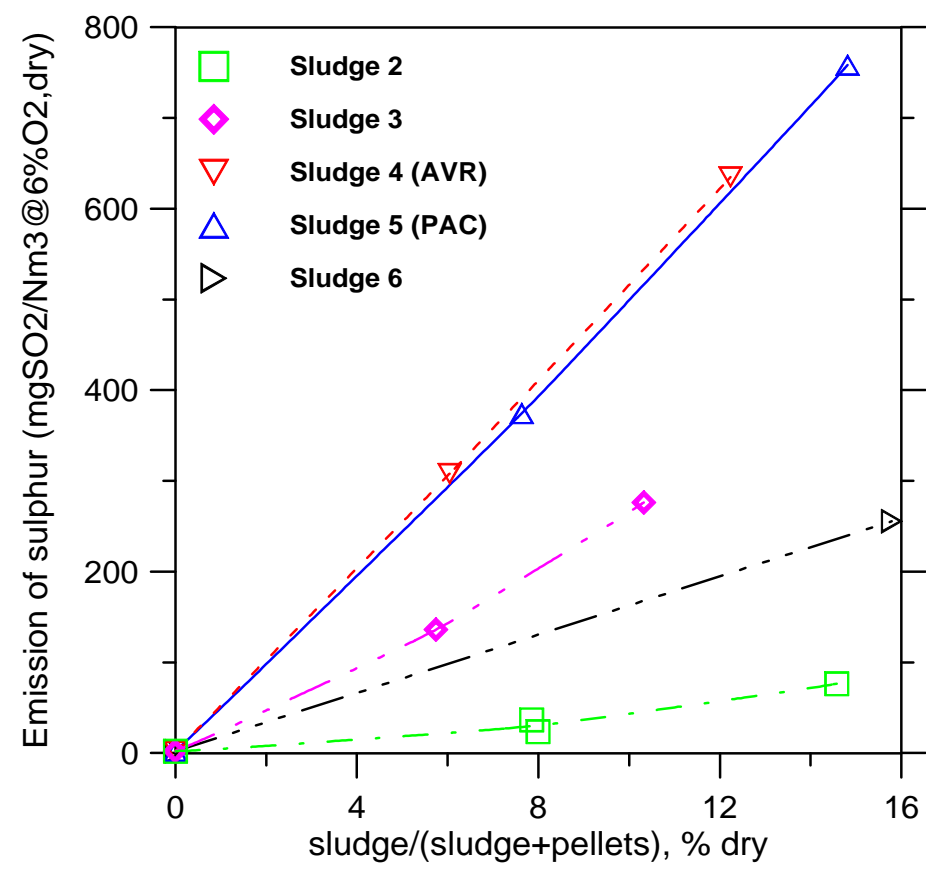

Figure 15. Influence of co-combustion of mechanically dewatered pulp and paper sludge with wood pellets on the emissions of $\mathrm{SO}_{2}$.

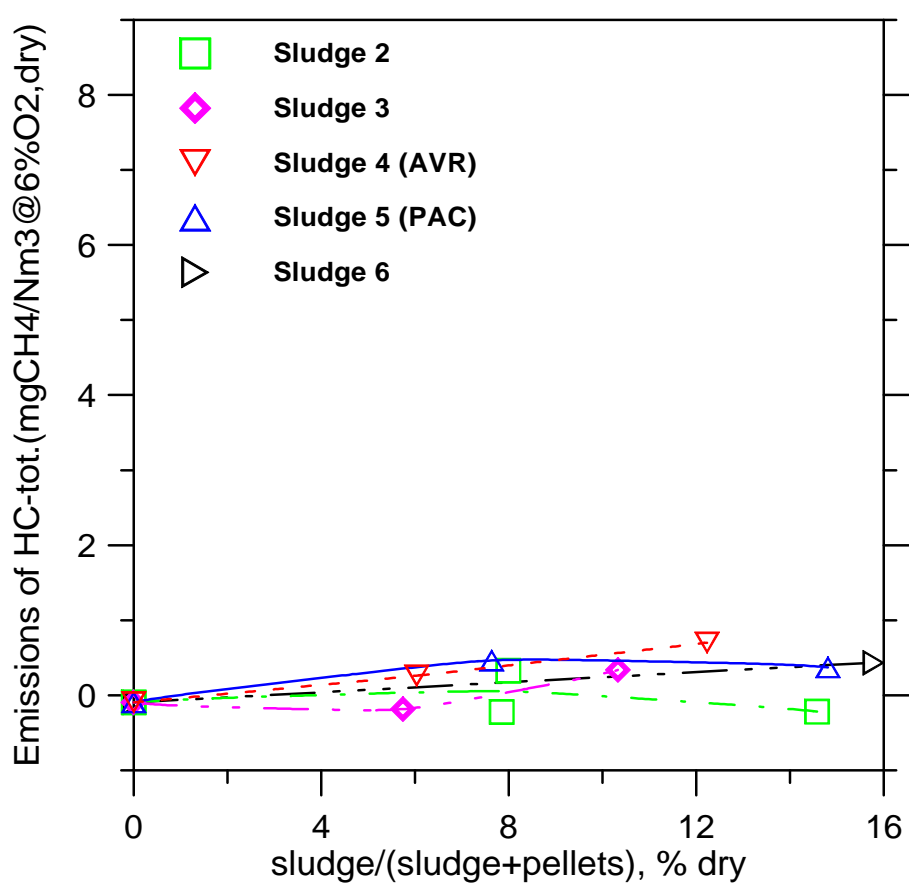

Figure 17. Influence of co-combustion of mechanically dewatered pulp and paper sludge with wood pellets on the emissions of total hydrocarbons (HC-tot.). 


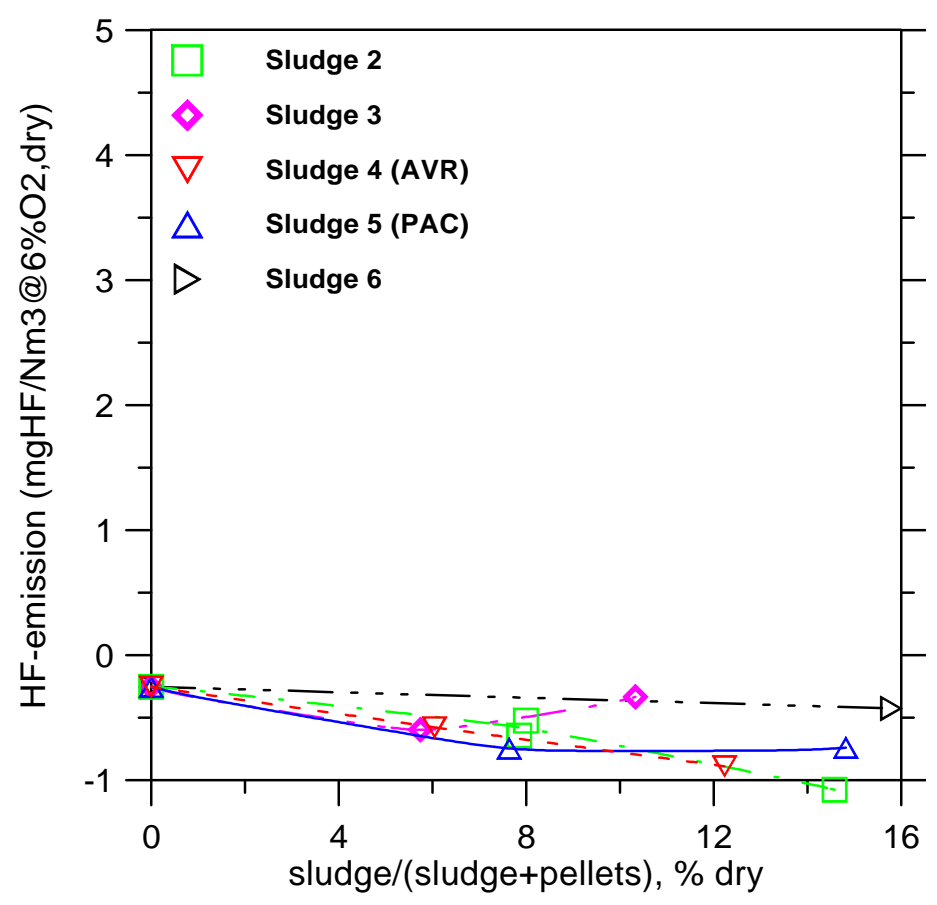

Figure 18. Influence of co-combustion of mechanically dewatered pulp and paper sludge with wood pellets on the emissions of HF.

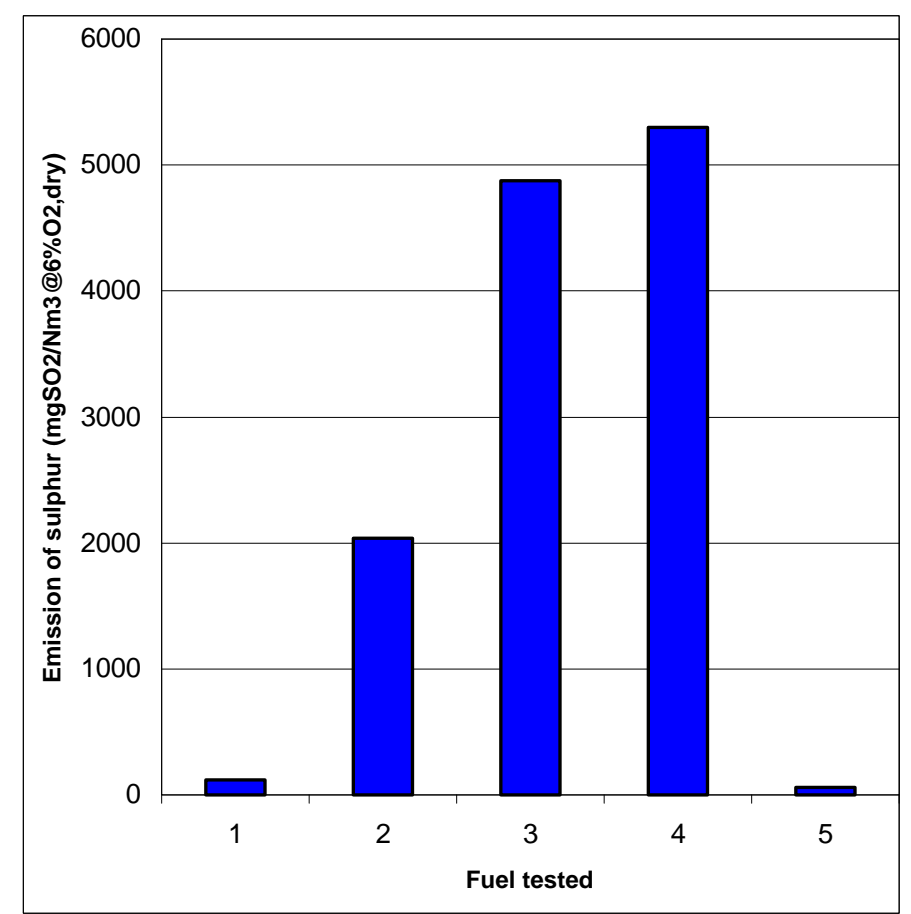

Figure 20. $\mathrm{SO}_{2}$ emission from tests performed in the laboratory unit. Fuels tested: 1. Sludge 2; 2. Sludge 3; 3. Sludge 4 (AVR); 4 . Sludge 5 (PAC); 5 Wood pellets.

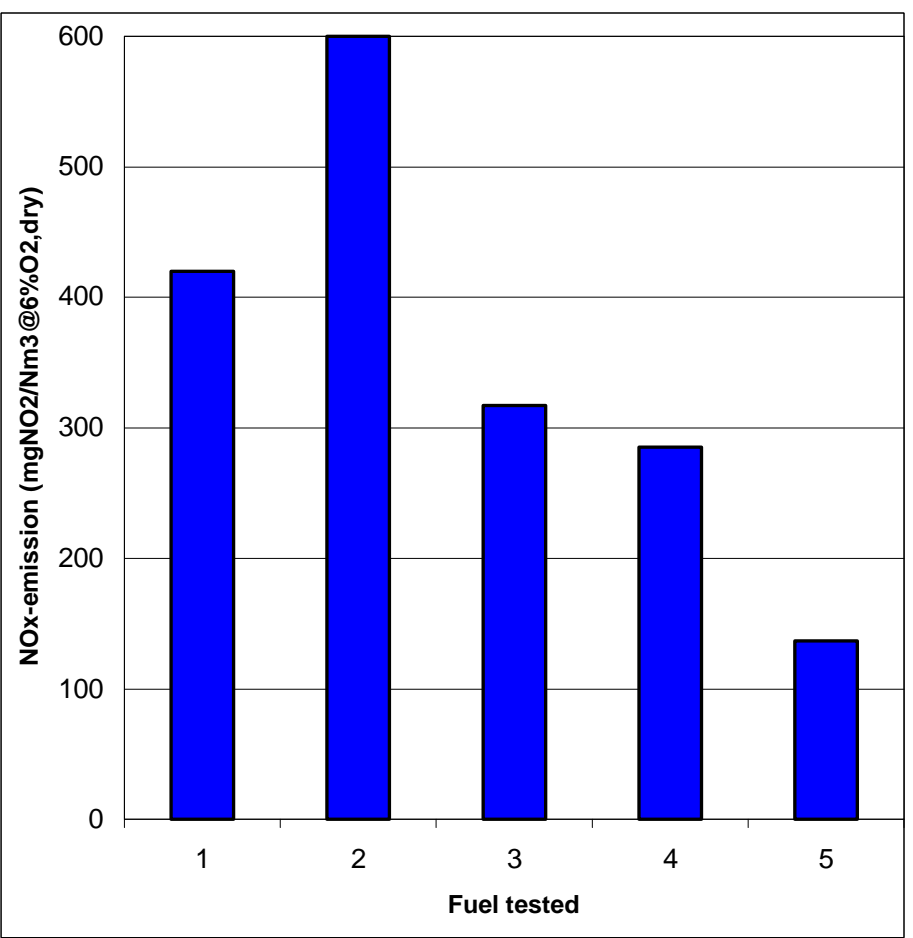

Figure 19. NOx emission from tests performed in the laboratory unit. Fuels tested: 1 . Sludge 2; 2 . Sludge $3 ; 3$. Sludge 4 (AVR); 4 . Sludge 5 (PAC); 5 Wood pellets.

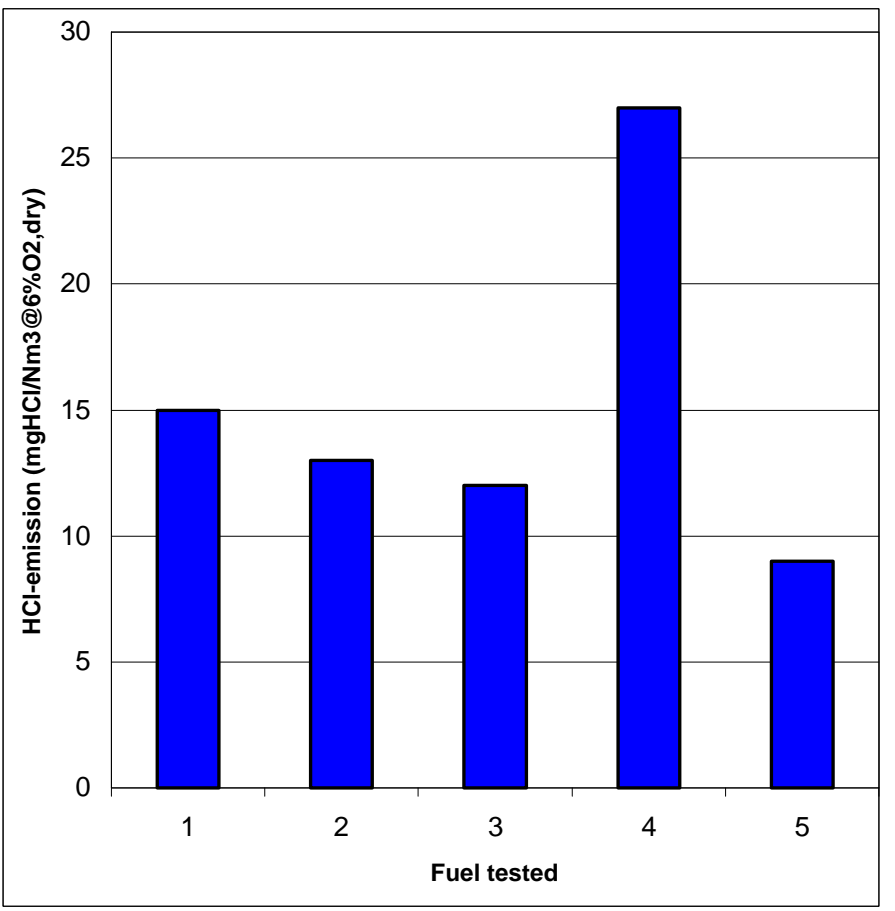

Figure 21. $\mathrm{HCl}$ emission from tests performed in the laboratory unit. Fuels tested: 1. Sludge 2; 2. Sludge 3; 3. Sludge 4 (AVR); 4 . Sludge 5 (PAC); 5 Wood pellets. 